\title{
National Economy Competitiveness of Kazakhstan Republic
}

\section{Irena Macerinskiene ${ }^{1}$, Gaukhar Sakhanova ${ }^{2}$}

\author{
${ }^{1}$ Mykolas Romeris University \\ Ateities st. 20, LT-08303, Vilnius, Lithuania \\ e-mail: irena.macerinskiene@mruni.eu \\ ${ }^{2}$ Abai Kazak National Teachers' Training University \\ Dostuk st. 13, Almaty, Kazakhstan \\ e-mail: ecolady@mail.ru
}

crossref $\mathrm{http}: / / \mathrm{dx}$.doi.org/10.5755/j01.ee.22.3.519

One of the criteria for the national economy growth of Kazakhstan Republic is its dynamic integration with national economies of the developed countries. Growth and merger of national companies at the macro and micro level is one of the priorities for the economy of each state including our country. Today in the Republic of Kazakhstan in the age of globalization, more than ever we need a system of complex measures in financial and trade sectors for its sustained development.

Te article analyzes the situation of the competitiveness of the national economy of Kazakhstan. This research was aimed at studying the theoretical and methodological approaches for a development of competitive national economy in the context of globalization as well as developing practical recommendations for further economy development, which allowed to make several conclusions and recommendations arising from the aims and objectives set by the author. In the first part of this article, perspectives of national competitiveness are analyzed. In the second part of the article methodology of international competitiveness measurement is presented. In the third part of the article the analysis of Republic of Kazakhstan competitiveness is done. The results showed that there are many controversies in competitiveness definition and measurement. One of the examples is evolution of Kazakhstan's competitiveness in 2010 due to some activities by IMF and WEF. Though the measurements include many similar factors of competitiveness, the main competitive advantage of Kazakhstan is a huge reserve of mineral resources and stable macroeconomic situation. The main weaknesses are low innovation capability and high corruption rate.

Keywords: competitiveness, competitiveness factors, economic development, GDP (gross domestic product).

\section{Introduction}

One of the criteria of the Republic of Kazakhstan economy growth is its dynamic integration with national economies of the developed countries. Growth and merger of national companies on the macro and micro level are the priority sectors of the economy of any country, including our country. In the age of globalization Republic of Kazakhstan, more than ever needs to find ways which lead to sustained development. In his each annual message President N. Nazarbaev pays great attention to the economic bloc of the state development. In his message to the people of Kazakhstan "New decade - new economic rise - new opportunities of Kazakhstan" dated from January 29, 2010, the President noted that: "World financial and economic crisis affected the rate of economy growth, but did not cease our development. Accumulated economic potential helped ensure stability for us in the hardest crisis battles in the last three years".

Why some nations prosper and others do not? This has been one of the central questions in economics, yet there remains a considerable debate about what factors determine national competitiveness. Still there is little agreement as what competitiveness actually means or how it can be conceptualized (Berger 2008).

Problems and aspects of competitiveness in Lithuania were analyzed by Balkyte \& Tvaronaviciene (2010), Staskeviciute \& Tamosiuniene (2010), Rutkauskas (2008), Snieska \& Bruneckiene (2009), Pukeliene \& Maksvytiene (2008), Tvaronavicius \& Tvaronaviciene (2008), Ginevicius \& Podvezko (2009), Kilijoniene, Simanaviciene \& Simanavicius (2010), Zavadskas \& Kaklauskas. (2008), Bruneckiene, Guzavicius \& Cincikaite (2010) and others.

The main problem is how to evaluate national economy competitiveness. The object is national competitiveness. The aim is to evaluate Republic of Kazakhstan national economy competitiveness of Kazakhstan Republic. The objectives of the article are as follows:

- to discover the definition of competitiveness;

- to identify the main theoretical and practical aspects evaluate of national economy competitiveness;

- to present the results of the research on Republic of Kazakhstan national economy competitiveness of Kazakhstan Republic.

Methods of research: comparative analysis of scientific literature, statistical analysis.

\section{Evolution of competitiveness definition}

The interest, why some countries are more competitive than others arose already in XVI century (Staskeviciute, Tamosiuniene, 2010). Since then the definition of national competitiveness has changed and now it involves many aspects. In different time periods three diferent perspectives to competitivness can be defined (Staskeviciute, Tamosiuniene, 2010). 
In XVI-XVIII century countries competitivness was commensurate with the balance of trade. At that time mercantilizm theory was popular (Humphery 1999, Reljan et. al. 2000). Gold, silver, and trade value was understood as the main capital which determined prosperity of a nation. If national gold reserve was growing, than the country was competitive. Foreign trade barriers were imposed to encourage exports and discourage imports of goods to keep gold reserve growing. But this soon was considered as inefficient. Nations needed another perspective of national competitiveness, which would help to find factors leading to prosperity.

In the XVIII-XX century national competitiveness was evaluated as low production costs. At that time ideas of classical economics dominated (Adam Smith, Jan-Babtiste Say, David Ricardo, Thomas Malthus et al.). Classical economy was associated with the idea that free markets could regulate themselves. Nation, which could produce goods with lower costs and sell in international market, got competitive advantage over other nations. From this perspective national economy competitiveness meant the ability of national companies to produce goods and services under the price and quality not worse than goods of foreign producers and satisfying both foreign and domestic consumers (Nurmukhanova, 2008). Business productivity and efficiency are important for national competitiveness, but global economy is too complex to be explained by traditional theories.

At the beginning of the XX century crucial position of low production costs was disputed. New factors determining national competitiveness were included. Followers of Keynesian economics argue that governments' economic policy is the factor influencing national competitiveness (Thurow, 1992). Vernon (1966) related competitive advantage to production life cycle and stressed innovation as the main factor of competitiveness (Staskevičiūtė, Tamošiūnienè, 2010). J. Schumpeter (1942) also emphasized the role of innovation and entrepreneurship to competitiveness. He affirmed that only entrepreneurship and innovations destroy balance of economy and create growth (Dabic, 2011). So innovation has become the main element of competitiveness. In the modern economic approach the main factor of competitiveness has become knowledge (Staskeviciute, Tamosiuniene, 2010). Innovation is important, because it creates new knowledge and so increases competitiveness. Porter tried to integrate all theories and created diamond model, where four broad factors of competitiveness and their relations were included: factor conditions, demand conditions, relating and supporting industries, and company strategy, structure, and rivalry, which create the environment in which companies are born and learn how to compete (Subarna \& Rajib, 2010). In this model competitiveness is defined as the nation's ability to create environment, which helps enterprises innovate faster than foreign competitors. Porter emphasizes productivity growth as the focus for national strategies.

At the end of the XX century social welfare became inherent for competitive nations. Competitive nation should ensure high quality of life: high living standards, quality education, social security, freedom of choice etc.
(Fagerberg, 1988, Landau, 1992, Aiginger, 2006). High employment rate is also one of the competitive features of the nation. Balkyte \& Tvaronaviciene (2010) argue that competetiveness refers to overall economic performance of a nation measured in terms of its ability to provide its citizens higher living standards on a sustainable basis and a broad choice of jobs to those willing to work. Competitive regions and cities are the places where both companies and people want to invest and to locate in (Kitson et al. 2004). Competitiveness of nations may be defined as the facts and policies that shape the ability of a nation to create and maintain an environment that sustains more value for its enterprises and more prosperity for its people (Subarna and Rajib, 2010).

Since now there is no common definition of a nation's competitiveness. National competitiveness has long been a relatively straightforward matter of the cost competitiveness of an economy internationally. National competitiveness is a complex of institutional and systemic factors relating to macro political economy issues and the ways in which they affect the microeconomic activities of companies within their competitive environments (Thompson, 2004). Staskeviciute, Tamosiuniene (2010) include nine aspects of national competitiveness, which are recently used in scientific literature. Those aspects are: high living standards, high employment, productivity, trade balance, and nation's attractiveness, ability to implement goals, policy, flexibility, and ability to sustain development. These aspects describe the most important features of national competitiveness and usually are measured to estimate competitiveness.

\section{International assessments of national competitiveness}

There is disagreement not only about competitiveness definition, but also about its measurement. The models of competitiveness are based on the selection and grouping of different factors of competitiveness into a general system (Balkyte, Tvaronaviciene, 2010). A wide range of complex competitiveness determinants could be found. Berger (2008) argues that national competitiveness can have a meaning if it is seen as a relative concept for comparisons, i.e. benchmarking of nations. Competitiveness indices are calculated by various international organizations and published annually. But international organizations use different measurement models, therefore results may vary.

International Institute for Management Development (IMD) publishes the World Competitiveness Yearbook, which provides extensive coverage of 58 economies. Competitiveness Yearbook has been attempting to gauge national competitiveness in terms of how the macropolitical and economic institutions of a country provide 'companies with an environment that sustains the domestic and international competitiveness' since 1980 (Garelli, 2004). For the WEF, national economic competitiveness is 'the set of institutions, policies and factors that determine the level of productivity of a country' (Sala-i-Martín et al., 2009: 4). The methodology that supports the World Competitiveness Yearbook is based on four pillars of competitiveness indicators (figure, 1), each of which is 
divided into five sub-categories (Balkyte, Tvaronaviciene, 2010). There are twenty components, each of which is given an equal weighting of 5 percent, when calculating an overall competitiveness rating. The indicators assessed in this report are based on "hard" data from international and national statistics, which represents $2 / 3$ in the overall rating, and opinion (survey) data (1/3). Total sum of indicators forms national competitiveness evaluation.

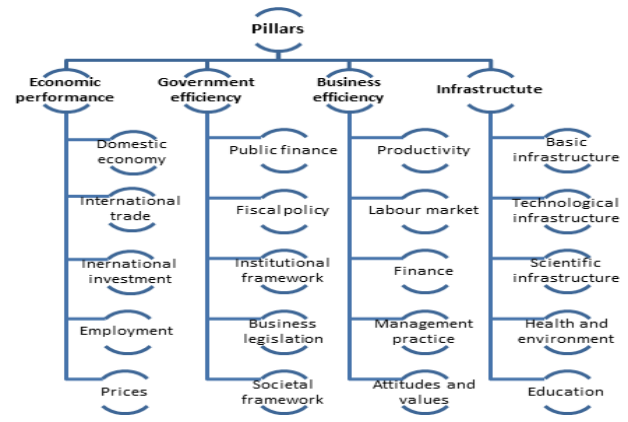

Figure 1. Four pillars of competitiveness (Garelli 2009)

World Economic Forum's (WEF) annual Global Competitiveness Reports has examined many factors enabling national economies to achieve sustained economic growth and long-term prosperity. It covers about 133 countries from the entire world. The total number of countries varies every year due to some countries involved and some eliminated. Global Competitiveness Report is co-chaired by Harvard Business School professor, Michael Porter, and incorporates an index developed by him based on his popular book Competitive Advantage of Nations (1990) (Thompson, 2004). World Economic Forum defines competitiveness as "the set of institutions, policies, and factors that determine the level of productivity of a country (Global Competitiveness Report 2010-2011).

Since 2005, the World Economic Forum has based its competitiveness analysis on the Global Competitiveness Index (GCI), which captures the microeconomic and macroeconomic foundations of national competitiveness. The Global Competitiveness Index (GCI) involves many different components, each of which reflects one aspect of the complex concept that is called competitiveness. All these components are grouped into 12 pillars of competitiveness (see Fig. 2). The pillars are organized into three sub-indexes, each critical to a particular stage of development: the basic requirements sub-index groups are those pillars most critical for countries in the factor-driven stage, the efficiency enhancers sub-index includes those pillars critical for counties in the efficiency-driven stage, and the innovation factors sub-index includes the pillars critical to countries in the innovation-driven stage (Schwab, 2009). The rankings are calculated from both publicly available data and the Executive Opinion Survey. In 2010, over 13,500 business leaders were polled in 139 economies. The survey is designed to capture a broad range of factors affecting economy's business climate.

There are two differences between WEF and IMD reports. First, WEF covers more economies (133 economies, 2009-2010) than IMD (59 economies, 2009). Second, the using of the "soft" and "hard" data is different - WEF puts more emphasis on survey data compared to the IMD with the more focus on "hard" statistics from international, national and regional organizations.

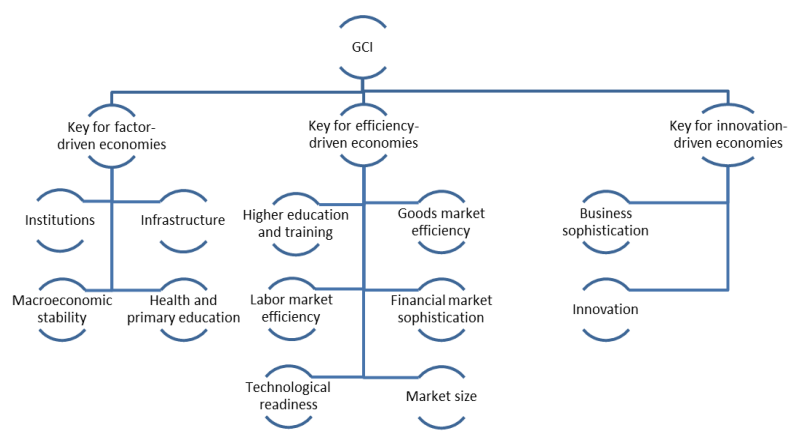

Figure 2. The 12 pillars of competitiveness (Schwab 2009)

\section{Modern state of Kazakhstan economy}

Prosperity is determined by the productivity of an economy, which is measured by the value of goods and services produced per capita, capital, and natural resources. Productivity depends both on the value of nation's products and services, measured by the prices in open markets, and the efficiency with which these products can be produced. Productivity supports high wages, a strong currency, and attractive returns to capital—and high standard of living (Porter et.al., 2008). Competitiveness, then, is measured by productivity. Index of Gross Domestic Product (GDP) is a basic indicator for country's development level in the world practice.

It is important to analyze the fluctuation of GDP growth rate of Kazakhstan. Within 2002 - 2009 GDP grew stably, and GDP per head (ignoring purchasing-power parity) increased from 1658 USD in 2002 to 68651 USD in 2009, which corresponds to high average level. When World Bank evaluated the status of Kazakhstan economy, it included our country into the group of countries with income above average world level (table 3).

In general, after the recession and stagnation period at the beginning of the $1990^{\text {th }}$, Kazakhstan economy entered the period of economic growth since 1999-2002, which was of recovery character largely, and since 2002 to present time we observe a stable high growth trend in economy.

In 2007, the country's economy continued to grow by quick paces despite world financial turmoil, and economic growth amounted to $8.9 \%$. It was caused by a high rate of development of the branches like processing industry, real estate operations, construction and trade. Almost all the branches of the country were registered by production volume gain in 2007: in industry $-4.5 \%$, agriculture $8.4 \%$, in the sphere of communication- $3.3 \%$, transport$4.9 \%$, and trade $-10 \%$. Growth of investments into fixed capital amounted to $8.2 \%$ as compared with 2006 .

It is worthwhile to say that principal internal growth factors of previous years were:

- expansion of internal aggregate demand, particularly consumer and investment;

- growth of investment volume, including emerging of public investments role;

- favorable investment climate, regulating inflow of direct foreign investments into the country; 
GDP of Republic of Kazakhstan in 2002-2009

Table 1

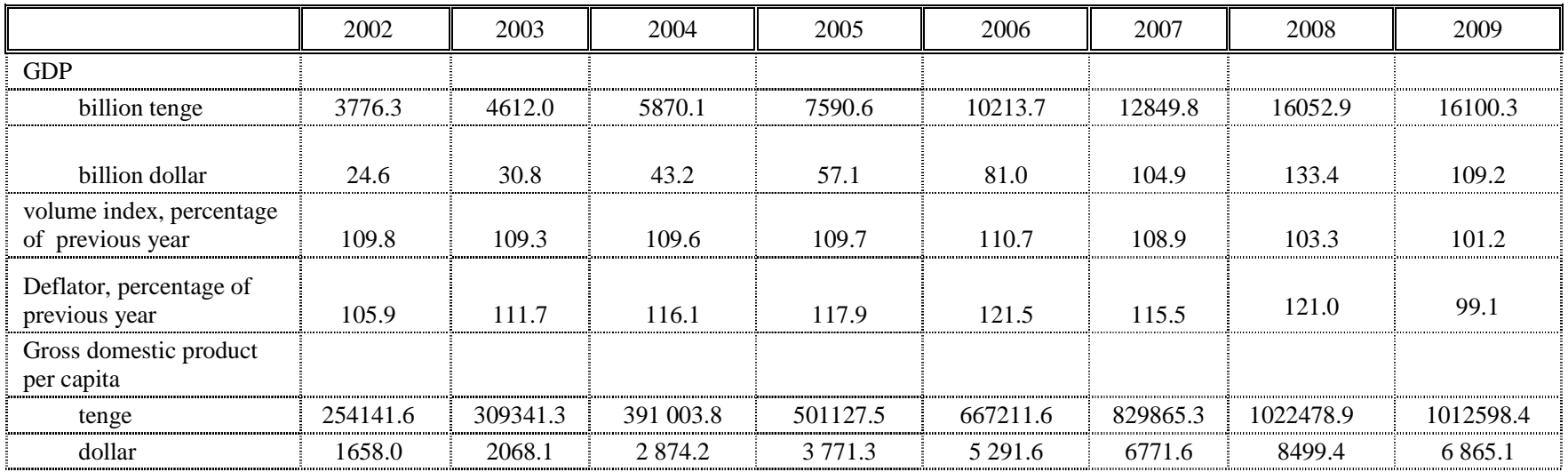

Note: Data Agency RK on Statistics

Moreover, keen demand conditions at the world market for the raw stuff have been formed in the last decade, especially for energy resources, either favorably influenced on the raw materials resources production development in Kazakhstan.

We observed price boom at the raw oil world market, which is a key energy market. For a period since 1998 local minimum time at the oil market 13.01 USD/barrel before 2007 cost of crude oil in money terms exceeded 100 USD/barrel, cost of one oil barrel depending on the crude oil grade increased more than 10 times.

Mainly such situation was caused by a quick rate of the world economy growth, particularly of the USA and China economy, and by low-level of free production facilities for oil extraction, which did not enable to increase extraction quickly to meet growing demand for oil. Primary growing of demand for oil and natural gas was conditioned as a result by the price competitive strength of these energy products and by the increase of their supply as well as by the absence of competitive not oil-based alternative fuels. The main source of GDP growth is still export of commodities and products with low degree of industrial processing.

In the last decade Kazakhstan showed extraordinary speed of development and this growth continued in the world financial crisis period. However, a large portion to economic growth of Kazakhstan was contributed by its natural resources - oil and gas industries and the mining sector. Indeed, the oil and gas sector is now Kazakhstan's biggest export category and a vital force behind the nation's economic growth. Nevertheless, it is debatable whether oil and gas industry alone can provide long-term economic development for this economy. Consequently, due to the rise of wages, shortage of professional and skillful labor, pressures of environmental protection and insufficient infrastructure, Kazakhstan is now facing new challenges.

\section{Kazakhstan's stage of competitive development}

Success of competitive development policy mostly depends on the stages of macroeconomic development, which actually creates primary conditions for the transition to a higher level of development of the national economy (Rogacheva, 2008). Huge differences exist in competitiveness structure of each country, because it is impossible for a country to be competitive in all or most of the fields (Rutkauskas 2008: 91). Porter discussed the four stages of competitive development: factor-driven, investment-driven, innovation-driven, and wealth-driven stages. Consequently, countries pass through these four stages in creating competitive advantage of their nation and in enhancing its economic prosperity. However, this model has been criticized due to the inapplicability to small and developing economies, and it is overlooking the roles of multinational enterprises and foreign direct investment (Lee and Akhmetova, 2009).

World Economic Forum defines three stages of economic development: factor driven stage, efficiency driven and innovations driven. There are also two transitive stages defined. Countries are allocated to the stages of development based on two criteria. The first is the level of GDP per capita. Second criterion measures the extent to which countries are factor driven. The main indicator is the share of exports of mineral goods in total exports at the market exchange rates.

Factor driven stage characterizes countries with the lowest level of development. These countries compete based on their factor endowments: primarily unskilled labor and natural resources. The economy has a low degree of integration into the world economy; therefore economy is particularly susceptible to fluctuations in the world economic cycle, commodity prices, and exchange rates. For this category of countries price is the main asset within global competitiveness. In order to move into the second group of countries the assimilation of technologies through import, direct foreign investments and imitation are necessary for them.

Many of these features characterize Kazakhstan economy. Kazakhstan has comparative factor advantages in the form of huge reserves of mineral resources. The main source of GDP growth is still export of commodities and products with a weak degree of industrial processing (Rogacheva, 2008). Also the highest competitive ranking is given for basic requirements sub-index. Some features of the 
Kazakhstani economy remain in the factor-driven stage and others are pushing forward into the investment-driven stage of economic development. The country is investing in its infrastructure, encouraging and capitalizing on foreign economic participation, and producing basic goods and services.

Investment-driven stage characterizes countries with middle income, where growth depends on investments, and competitiveness is achieved through the use of world technologies in domestic production. More efficient production processes and increase product quality is developed.

Increasingly, oil and gas activities in Kazakhstan are being developed which have, for example, spawned important industry players in the petrochemical sector. Furthermore, new technologies are being applied in oil extraction and recovery, suggesting emergent, innovationdriven activity (Rogacheva, 2008). These features show that the growth of Kazakhstan becomes dependent on investment in new technologies. This lets increase competitiveness and reach investment-driven stage of development.

Finally, as countries at the innovation-driven stage are able to sustain higher wages and the associated standard of living only if their businesses are able to compete with new and unique products. Kazakhstan's innovation capability is the weakest point of all competitive structures. Huge investments and improvements of innovation infrastructure are needed, to reach this stage of development.

Kazakhstan is in the transitive stage from factor driven to efficiency driven stage. According to the goods classification of OECD, Republic of Kazakhstan has a status of the country that produces mostly average - and low technological traditional goods. By the level of economic development the country is on the level of preindustrial and industrial development stage in the group of other developing countries. Many competitiveness factors should be improved to go to the investment driven stage, where investment and higher level of productivity ensure higher prosperity.

\section{International competitiveness of Kazakhstan economy}

Kazakhstan as small and open economy relating to the financial-trade relations global system's market is actively in contact with the entities of the system. Of course, any country encountering external world must define its place and improve its positions there.

In 2009 Kazakhstan was for the first time included in World Competitiveness rakings of IMF and won $36^{\text {st }}$ place out of 59 countries of the world. The strongest pillar of competitiveness is government efficiency $\left(20^{\text {st }}\right.$ place 2010). The weakest pillar is economic performance $\left(43^{\text {st }}\right.$ place 2010), where international trade is evaluated at the lowest $55^{\text {st }}$ place out of 58 countries. Comparing 2009 and 2010 results Kazakhstan improved its total competitiveness ranking by three places; also it improved in all pillars especially in infrastructure and business efficiency.

In 2005 , the country for the first time was included in WEF competitiveness rating and won $61^{\text {st }}$ place out of 117 countries of the world. Next year (2006) methodology of competitiveness evaluation changed. The WEF renamed the Competitive growth index, increased number of evaluation criteria, now it is called as a global competitive index. In 2006 Kazakhstan took $51^{\text {st }}$ place in the view of the 2005 rating reassessment, for the most part thanks to positive dynamics of national measures. Though other parameters testified worsening of its positions. Thus, actually under the calculations at the end of 2005, Kazakhstan takes the $56^{\text {th }}$ place among 125 countries in 2006. In 2007 the WEF changed calculation parameternumber of countries investigated increased - from 125 to 131. Moreover, in 2008 Kazakhstan cut other 5 positions in the rating table by taking $66^{\text {th }}$ place among 134 . Nevertheless, the year 2009 became a witness of many positions deterioration. Kazakhstan takes $67^{\text {th }}$ place out of 133 countries in the world in the GCI 2009 rating.

Competitiveness of Kazakhstan for 2010 got 4.1 grades (1 to 7 available) total competitiveness evaluation. The same total evaluation was published in the 2009 and 2008 year reports. Though, the value of different indicators has changed. The position of Kazakhstan's competitiveness decreased. In 2010 ranking Kazakhstan got $72^{\text {th. }}$ place and slumped down by 5 positions, comparing with 2009. This may be the result of the changed methodology of calculation and amount of countries involved in GCI report. Also it may show weakening competitive positions in the world market.

Comparing 2009-2010 and 2010-2011 results we can see sharp increase of basic requirements sub-index (see table 2). Basic requirements sub-index is evaluated at the highest level comparing with other sub-indexes. In this sub-index main Kazakhstan's competitive advantage is macroeconomic stability. In this pillar 2009-2010 WEF defined three indicators from five where Kazakhstan had notable competitive advantage. It is government surplus/deficit, national savings rate and government debt. In 2010-2011 report one more indicator from this pillar was defined as competitive advantage: interest rate spread, which increased ranking from $109^{\text {th }}$ place in $2009-2010$ to $23^{\text {rd }}$ place in $2010-2011$.

Table 2

Dynamic of Kazakhstan competitivnes evaluations

\begin{tabular}{|l|l|l|l|}
\hline & $\begin{array}{l}2009- \\
2010\end{array}$ & $\begin{array}{l}2010- \\
2011\end{array}$ & Change \\
\hline GCI & 4.1 & 4.1 & \\
\hline Basic requirements & 4.3 & 4.5 & 0.2 \\
\hline Institutions & 3.6 & 3.6 & \\
\hline Infrastructure & 3.5 & 3.6 & 0.1 \\
\hline Macroeconomic environment & 4.7 & 5.3 & 0.6 \\
\hline Health and primary education & 5.2 & 5.5 & 0.3 \\
\hline Efficiency enhancers & 4.0 & 4.0 & \\
\hline Higher education and training & 4.1 & 4.2 & 0.1 \\
\hline Goods market efficiency & 4.0 & 4.0 & \\
\hline Labour market efficiency & 4.9 & 4.9 & \\
\hline Financial market development & 3.5 & 3.4 & -0.1 \\
\hline Technological readiness & 3.5 & 3.4 & -0.1 \\
\hline Market size & 4.2 & 4.2 & \\
\hline $\begin{array}{l}\text { Innovation and sphistication } \\
\text { factors }\end{array}$ & 3.4 & 3.1 & -0.3 \\
\hline Business sophistication & 3.7 & 3.5 & -0.2 \\
\hline Innovation & 3.1 & 2.8 & -0.3 \\
\hline
\end{tabular}


From the institutions pillar, which consist of 21 indicators, as competitive advantage in 2010-2011 there was noted public trust of politicians and strength of investors protection. But other indicators such as property rights (112), juridical independence (109), reliable police services (113) and protection of minority shareholder's interest (116), looked relatively weak.

Infrastructure pillar results has increased from 3.5 in 2009-2010 to 3.6 in 2010-2011 from 7 points available. Such increase let increase ranking by five positions to the 81-st place in the world. Kazakhstan has a notable competitive advantage in the quality of railroad infrastructure. But the quality of roads is the weakest point in the infrastructure pillar and the ranking is still decreasing (116 ${ }^{\text {th }}$ place in $2009-2010$ to $124^{\text {th }}$ place in $2010-2011$ ).

Health and primary education pillar evaluations have increased by 0.3 points to 5.5 in 2010-2011. Since 2009 Kazakhstan has got the first place regarding malaria and malaria incidence indicators. Also Kazakhstan has competitive advantage at HIV prevalence. But low ranking results have been got from tuberculosis incidence. Also life expectancy has low results, $106^{\text {th }}$ place (2010-2011).

Basic requirements sub-index is ranked at the highest level comparing with other sub-indexes. Almost all pillars from this sub-index have increased its rankings in 20102011 periods. The main strength is efficient macroeconomic policy. But still there are many indicators where the results can be improved.

Efficiency enhancers' total sub-index is evaluated by 4 points out of 7 and has not changed in 2009-2010. But the pillars which structure sub-index evaluations have changed in both positive and negative directions. Positive increase was seen in higher education and training pillar (from 4.1 to 4.2 in 2009-2010). Decrease was seen in the financial market development and technological readiness indicators. Though the Kazakhstan financial market is only being formed, it is all the same exposed to external causes, in this particular case to negative effect of the world economic crisis.

There can be defined many competitive advantages in the labor market efficiency pillar: flexibility of wage derermination, rigidity of employment, hiring and firing practices, firing costs, pay and productivity, female participation in labor force. This pillar is ranked at $21^{\text {st }}$ place in 2010-2011 and ranking decreased by 3 positions, though evaluation in points has not changed. This shows that situation in other countries labor market improved.

Innovation and sophistication sub-index is evaluated at the lowest level and this evaluation is decreasing. Kazakhstan's ranking decreased by 24 positions to $102^{\text {nd }}$ place in 2010-2011. Such slump determined the decrease of total competitiveness index. Innovation is the main factor of productivity and competitiveness growth and decrease in this capability may be harmful for future. Innovation development strategy of the Republic of Kazakhstan is affirmed by the President's Decree of the Republic of Kazakhstan and aims, on one hand, at achieving stable development of the Republic of Kazakhstan by means of economy diversification and, on the other hand, ignoring raw oriented development where innovation is considered to be as a major factor in competitiveness of the national economy (Umirzakov, 2007). The main characteristic is the creation of scientific parks, innovation technological centers, innovation incubators and other similar structures, oriented to rapid realization of scientific research results into HOBYJO techniques, technology and materials (Umirzakov, 2007). However, WEF innovation capability evaluation is low and is decreasing, which can deter future growth.

Business notes such problematic factors as corruption, inadequate educated workforce, hard access to finance and inefficient government bureaucracy. These factors hinder entrepreneurship activities, and negatively effect competitiveness.

To sum up, the main strengths of Kazakhstan is macroeconomic stability. The main weakness is innovation capability. As we can see there are huge differences in indicators consisting global competitiveness index. Every country has to establish its own competitiveness level and find its own opportunities to win its share in the global market. Leading countries give their model how to achieve competitive advantage, but these models may not fit other countries, due to high changes in global market.

\section{Conclusions}

There is no common definition or measurement model of competitiveness. Competitiveness includes such aspects as high living standards, high employment, productivity, trade balance, nation's attractiveness, ability to implement goals, policy, flexibility, and ability to sustain development. The importance of these aspects in the competitiveness measurement depends on the researcher. Though, competitiveness measurement models of international organizations are alike, many factors measured are similar, but data is collected from different sources. WEF puts more emphasis on survey data compared to the IMD. Also ranking methodology changes and it is becoming hard to compare results over time.

According to IMF, Kazakhstan improved its total competitiveness ranking in 2010 by three places. Opposite competitiveness evolution is defined in WEF report. WEF defined that the position of Kazakhstan's competitiveness was decreasing by 5 positions in 2010 . This shows that the models used in measuring competitiveness are inconsistent.

Economy of Kazakhstan is growing fast. But mainly this development is influenced by its natural resources - oil and gas industries and the mining sector. The country is investing in its infrastructure, encouraging and capitalizing foreign economic participation. Economy is in the transitive stage from a factor driven to efficiency driven stage.

The main competitive advantage of Kazakhstan is huge reserves of mineral resources and stable macroeconomic situation. The main weakness is innovation capability, high corruption rate. Thereby, if we judge by the standards of WEF' competitive strength, then Kazakhstan in the first instance needs to improve institutional bases of market economy, increase its transparency and reduce corruption level, and pay greater attention to the technological and innovative development of the country. In the view of a goal to increase the country's competitive strength, it is also necessary to 
improve the living standards of the population, increase an employment growth, decrease an unemployment rate and a population income gap as well as the rise of labor productivity.

Consequently, firstly, the growth of innovativetechnological constituent for economic development becomes the main parameter that should be raised by the country. Secondly, the improvement of economy social orientation, which gives an additional impulse for an economic growth due to the increase in consumer demand and form a set of branches important from the viewpoint of the general competitive strength of the country - health, education and science. Thirdly, to create an appropriate business-environment. Taken together it stipulates the conduction of a successive economic policy the goal whereof is to ensure competitive advantage of the country.

\section{References}

Aiginger, K. (2006). Competitiveness: from a dangerous obsession to a welfare creating ability with positive externalities, Journal of Industry, Competition and Trade 6, 161-177.

Balkyte, A., \& Tvaronaviciene, M. (2010). Perception of Competitiveness in the Context of Sustainable Development: Facets of "Sustainable Competitiveness. Journal of Business Economics and Management, 11(2), 341-365

Berger, T. (2008). Concepts on National Competitiveness. Journal of International Business and Economy, 9(1), 3-17.

Bruneckiene, J., Guzavicius, A., \& Cincikaite, R. (2010). Measurement of Urban Competitiveness in Lithuania. Inzinerine Ekonomika-Engineering Economics 21(5), 493-508

Dabic, M., Cvijanovic, V., \& Gonzales-Laureiro, M. (2011). Keynesian, Post Keynesian vs. Schumpeterian NeoSchumpeterian: an Integrated Approach to the Innovation Theory. Management Decision, 49(2)

Garelli, S. (2004). Competitiveness of Nations: The Fundamentals. IMD World competitiveness yearbook 2004. Available from Internet: http://theme.cepd.gov.tw/Dipper8/electric\%20book/IMD2004/wcy/intro/fundam.pdf

Garelli, S. (2009). IMD World Competitiveness Yearbook 2009. Lausanne: International Institute for Management Development. 21st. Ed. 543 p. ISBN-10, 2970051435.

Ginevicius, R., \& Podvezko, V. (2009) Evaluating the changes in economic and social development of Lithuanian counties by multiple criteria methods. Technological and Economic Development of Economy, 15(3), 418-436

IMD World Competitiveness Center (2010). World Competitiveness yearbook. 2010 Results.

Kilijoniene, A., Simanaviciene, Z., \& Simanavicius, A. (2010). The Evaluation of Social and Economic Development of the Region. Inzinerine Ekonomika-Engineering Economics, 21(1), 68-79

Kitson, M., Martin, R., \& Tyler, P. (2004). The Regional competitiveness: An Elusive yet Key Concept? Regional Studies 38(9), 991-999.

Jung Wan, L., \& Akhmetova, S. (2009). The Effects of Foreign Direct Investment on Economic Growth of a Developing Country: from Kazakhstan. Proceedings of the Academy for Economics and Economic Education, 12(2).

Nurmukhanova, G. (2008). Competitiveness of National Economy: Problems of Regulation. E+M Ekonomie a Management, Technical University of Liberec, 2.

Porter, M. Delgado, M. Ketels, C., \& Stern, S. (2008). Moving to a New Global Competitiveness Index. World Economic Forum, Global Competitiveness Report 2008-2009.

Progress Report on the government to improve the performance of the global competitiveness index for 2007-08. RK 1 half of 2008. Ministry of Economy and Budget Planning of Kazakhstan .- Astana, July 2008. - 67. Available online:http://www.minplan.kz/upload/iblock/bad/xcvsmh\%20itogi\%202008.doc

Pukeliene, V., \& Maksvytiene, I. (2008). Economy Scale Impact on the Enterprise Competitive Advantages. Inzinerine Ekonomika-Engineering Economics (2), 49-54.

Report of the IMF: World Economic Situation and Prospects as of mid - 2009. 26. Available online: http://www.un.org/ru/documents/ods.asp?m=E/2009/73

Rogacheva, T. (2008). Economy of Kazakhstan in Competitive Dimension. Intellectual Economics, 2(4), 81-88.

Rutkauskas, A. V. (2008). On the Sustainability of Regional Competitiveness Development Considering Risk, Technological and Economic Development of Economy, 14(1), 89-99.

Sala-I-Martin, X., Blanke, J., Drzeniek Hanouz, M. Geiger, T., \& Mia, I. (2009) The Global Competitiveness Index 20092010, contributing to longterm prosperity amid the global economic crisis, in K. Schwab (Ed) The Global Competitiveness Report 2009-2010 (Geneva, World Economic Forum).

Schwab, K. (2009). The Global Competitiveness Index 2009-2010: Contributing to Long-Term Prosperity amid the Global Economic Crisis, in The Global Competitiveness Report 2009-2010. Geneva: World Economic Forum, 3-47. Available from Internet: <http:// www.weforum.org/pdf/GCR09/GCR20092010fullreport.pdf>. ISBN-13, 978-9295044-25-8.

Snieska, V., \& Bruneckiene, J. (2009). Measurement of Lithuanian Regions by Regional Competitiveness Index. Inzinerine Ekonomika-Engineering Economics (1), 45-57.

Staskeviciute, I., \& Tamosiuniene, R. (2010). The Competitiveness of a Country: Evolution of a Concept. Business theory and practice, 11(2), 159-167. 
Irena Macerinskiene, Gaukhar Sakhanova. National Economy Competitiveness of Kazakhstan Republic

Subarna, K. S. \& Rajib, N. S. (2010). National Competitiveness and Perception of Corruption. Advances in Competitiveness Research, 18 (1/2), 89-101.

The Global Competitiveness Report 2008-2009. World Economic Forum, Geneva, Switzerland, 2008 Electron. resource Access Regime : http://www.scribd.com/doc/7471885/The-Global-Competitiveness-Report-20082009.

Thompson, E. R. (2004). National Competitiveness: A Question of Cost Conditions or Institutional Circumstances? British Journal of Management, 15, 197-218

Thurow, L. (1992). Head to Head: the Coming Economic Battle Among Japan, Europe and America. New York: Warner Books.

Tvaronavicius, V., \& Tvaronaviciene M. (2008). Role of fixed investments in economic growth of country: Lithuania in European context. Journal of Business Economics and Management, 9(1), 57-64.

Umirzakov, S. (2007). Increase of national Competitiveness on Basis of Innovation. The Romanian Economic Journal 25, $179-186$.

What should be the world after the global financial crisis? Globalists - news, economy, society, culture and geopolitics. November 26, 2008, Economics. Available online: file://localhost/Н:/Каким\%20должен\%20стать\%20мир\%20 после\%20мирового\%20финансового\%20кризиса_\%20_\%20Глобалист.htm

Zavadskas, E. K., \& Kaklauskas, A. (2008). Model for Lithuanian construction industry development. Transformations in Business \& Economics, 7(1), 152-168.

Data Agency RK on Statistics. www.stat.kz

Irena Mačerinskienè, Gaukhar Sakhanova

Kazachstano Respublikos nacionalinès ekonomikos konkurencingumas

Santrauka

Šiuolaikiniame pasaulyje jokia šalis negali ignoruoti globaliujų pasaulio plètojimosi tendencijų, nes globalieji ryšiai ir pasaulio ekonominių santykių lyginamasis vertinimas yra vieni iš svarbiausių veiksnių, lemiančių šalies ekonomikos konkurencingumą.

Šiandien prioritetinis Kazachstano Respublikos Vyriausybès tikslas - nacionalinès ekonomikos konkurencingumas - gana silpnai teoriškai, metodologiškai ir analitiškai pagrịstas ir dèl to sunku ši tikslą tinkamai interpretuoti, i̇vertinti, valdyti ir prognozuoti. Dèl šios priežasties iškyla daug klausimų, susijusių su nacionalinès ekonomikos konkurencingumo augimo galimybėmis. Šiems klausimams spręsti reikalingas pasaulio mokslininkų demesys ir papildomi moksliniai tyrimai.

Pagrindinis šio tyrimo tikslas - išanalizuoti teorinius ir metodologinius nacionalinès ekonomikos konkurencingumo aspektus šalies ekonomikos plètros ir globalizacijos kontekste. Taip pat pateikti praktines rekomendacijas dèl tolimesnių ekonomikos konkurencingumo raidos tendencijų, kurios leistų padaryti išvadas pagal autoriaus išsikeltus tikslus.

Atlikus tyrimą, gauti rezultatai parodè, kad pagrindinès kryptys, formuojančios konkurencingą ekonomiką, turètų būti šios: infrastruktūros plètra ir ekonomikos reguliavimo mechanizmai, mokslinių, technologiniu ir inovaciniu gamybos pajègumu formavimas, intelektiniu paslaugu pramonės skatinimas ir plètra bei efektyvus žmogiškujų išteklių potencialo panaudojimas.

Padarytos išvados grindžiamos atliktu Kazachstano ekonomikos konkurencingumo tarptautiniu vertinimu. Remiantis PEF konkurencingumo standartais, nustatyta, kad Kazachstano Vyriausybė visų pirma turi pagerinti savo rinkos ekonomikos institucinę sistemą, padidinti jos skaidrumą ir mažinti korupciją, taip pat sutelkti dėmesi i technologijų ir inovacijų plètrą. Siekdama padidinti šalies konkurencingumą, privalo pagerinti gyvenimo sąlygas gyventojams, didinti užimtumą, mažinti nedarbą ir gyventojų pajamų atotrūkí, taip pat padidinti ekonomikos produktyvumą. Taigi, pagrindiniai veiksniai, kuriuos reikia tobulinti, yra inovacijų bei technologinių procesų plètojimasis šalyje. Kiti veiksniai: socialiai orientuotos ekonomikos skatinimas, kuris suteikia papildomą impulsą ekonomikos augimui dėl daugejusių vartotojų skaičiaus ir kitų sričių, labai svarbių nacionalinės ekonomikos konkurencingumui, plètojimosi, tokių kaip sveikatos apsauga ir švietimo ir mokslo sistema. Trečiasis veiksnys yra tinkamos verslo aplinkos sukūrimas. Taigi visais šiais veiksniais sukuriama nuosekli ekonominė politika, kuri gali užtikrinti šalies konkurencini pranašumą.

Raktažodžiai: konkurencingumas, konkurencingumo veiksniai, ekonomikos plètra, BVP.

The article has been reviewed.

Received in March, 2011; accepted in June, 2011. 